\title{
Model Technopreneur IT Mahasiswa Pada Masa Pandemic Covid 19 dengan Metode Business Model Canvas
}

\author{
John Roni Coyanda ${ }^{1)}$ \\ ${ }^{1)}$ Fakultas Ilmu Komputer, Universitas Indo Global Mandiri \\ Jl. Jend. Sudirman No. 629, 20 Ilir D. IV, Kec. Ilir Tim. I, Kota Palembang, 30129 \\ Email : Coyanda@uigm.ac.id ${ }^{l)}$
}

\begin{abstract}
The corona virus is epidemic and, becoming a pandemic throughout the world, including Indonesia. This condition forces all people to remain at home to isolate themselves so as not to be exposed to the virus. Therefore, all activities become obstructed, especially those related to work to meet the needs of life. Even in some areas that fall into the red zone category, they have implemented Large Scale Social Restrictions (PSBB). This pandemic requires all students to fast adjust to new work patterns. students must study online. Although many activities cannot run as usual, we must remain optimistic to take business opportunities by using Technopreneur IT, businesses using applications for online bussines and business opportunities to continue online. This study aims to provide students with an understanding of the importance of having a idea creative in starting a business with IT applications to encourage the growth an entrepreneurial of Technology (Technopreneur) to students by introducing the Business Model canvas method, to introduce a business model that can be an alternative to starting a business and later able to be a job creator
\end{abstract}

Keywords : Technoprenerur, Bussines Model Canvas

\begin{abstract}
Abstrak
Virus corona sedang mewabah dan menjadi pandemi di seluruh dunia, termasuk Indonesia. Kondisi ini memaksa semua orang harus tetap di rumah mengisolasi diri agar tidak terkena virus. Oleh karena itu, semua aktivitas menjadi terhambat, terutama yang berhubungan dengan pekerjaan untuk memenuhi kebutuhan hidup. Bahkan di beberapa daerah yang termasuk kategori zona merah sudah menerapkan Pembatasan Sosial Berskala Besar (PSBB). Pandemi ini menuntut semua mahasiswa untuk cepat menyesuaikan diri dengan pola kerja baru. mahasiswa harus belajar secara online. Walaupun banyak kegiatan yang tidak dapat berjalan seperti biasanya, namun kita harus tetap optimis untuk mengambil peluang usaha dengan menggunakan Technopreneur IT, usaha menggunakan aplikasi untuk penjulaan secara online dan peluang usaha tetap berjalan dengan secara maya. Penelitian ini bertujuan untuk memberikan pemahaman kepada mahasiswa akan pentingnya mempunyai jiwa kreatif dalam memulai usaha dengan aplikasi IT untuk mendorong tumbuhnya jiwa kewirausahaan IT (Technopreneur) pada mahasiswa dengan mengenalkan metode Business Model canvas, untuk mengenalkan model usaha yang bisa menjadi alternatif untuk memulai usaha dan nantinya mampu menjadi pencipta lapangan kerja
\end{abstract}

Keywords : Technoprenerur,Bussines Model Canvas 


\section{Pendahuluan}

Pada masa penyebaran Corona yang sangat meluas mulai banyak cara dilakukan oleh pemerintah untuk menekan penyebaran mulai dari menerapkan Physical Distancing dan kini telah ditingkatkan menjadi PSBB (Pembatasan Sosial Berskala Besar). Menurut Pemenkes Nomor 9 Tahun 2020, PSBB Merupakan Pembatasan Kegiatan Tertentu Penduduk Suatu Wilayah yang diduga Terinfeksi Covid-19 Tujuannya yaitu Mencegah Penyebaran Covid-19 Disuatu Wilayah dan kini sudah secara resmi telah diterapkan oleh pemerintah. Kebijakan tersebut meningkatkan resiko sektor industri menghadapi gangguan signifikan dari sisi rantai pasok, tenaga kerja, kesinambungan bisnis hingga arus kas usaha mereka.

Menurut penelitian Driven Innovation Lab Singapore University Of Technology And Design prediksi usainya pandemi covid-19 di Indonesia akan usai dalam 3 waktu. Yakni 97\% di 7 Juni 2020, 99\% di 29 Juni 2020, dan $100 \%$ di 7 September 2020. Sedangkan untuk seluruh dunia, penelitian ini memperkirakan Covid-19 akan selesai pada Desember 2020.

Managing Partner Grant Thornton Indonesia, Johanna Gani, mengatakan kunci untuk bertahan adalah tetap optimistis dan selalu beradaptasi dengan keadaan. Pengusaha yang dapat menyusun rencana terstruktur baik di masa pandemi ini maupun setelah krisis mereda akan mampu bergerak lebih cepat kembali pada trajektori pertumbuhan seperti semula.

Pandemi Virus Corona ini mengakibatkan terganggunya hampir semua industri bisnis dari berbagi sektor, kecuali bidang kesehatan, dan merubah perilaku masyarakat dunia di semua kalangan. Ini menjadi tantangan yang sangat berat untuk ke depan, dimana selain menghadapi pandemi Virus Corona, bisnis ini dihadapkan pula dengan saatnya masuk puasa dan Lebaran, serta adanya tahun ajaran baru sekolah.

Karena kita harus menciptkan model untuk mahasiswa yang baru memulai usaha dan memiliki kemampuan untuk berinovasi dengan menciptakan ide bisnis yang sesuai dengan kondisi saat ini. Bahkan setiap negara harus merespon perubahan alam dan persaingan teknologi secara terintegrasi dan komprehensif. Respon tersebut dengan melibatkan seluruh pemangku kepentingan politik global, mulai dari sektor publik, swasta, akademisi, hingga masyarakat sipil sehingga tantangan pandemic Covid-19 di era revolusi industri 4.0 saat ini dapat dikelola menjadi peluang.

Saat ini, Pemerintah Indonesia menaruh perhatian yang tinggi dalam mengembangkan wirausaha mandiri di kalangan mahasiswa dari seluruh perguruan tinggi. Oleh karena itu setiap universitas di Indonesia didorong untuk mengajarkan kepada mahasiswa untuk memiliki dasar pengetahuan awal dengan mewajibkan setiap mahasiswa mengikuti mata kuliah kewirausahan dan praktikum langsung yang dapat memberikan kegiatan kreatif kewirausahaan dan memfasilitasi pengembangan serta inovasi. antara mahasiswa yang berpotensi untuk menjadi wirausaha muda, untuk membuka peluang usaha bersama dimasa Pandemik yang membuat perekonomian dan usaha kecil merosot perkembangan, dengan mencoba metode model technopreneur IT bussines canvas, ini akan muncul mahasiswa dengan ide serta kreativitas yang dapat memulai usaha. Dengan pola perkuliahan Daring di Universitas IGM, Mahasiswa program Studi Sistem Informasi dengan mata kuliah Praktikum Kewirausahan dan berkolaborasi dengan Mata kuliah Technopreurship dengan metode bisnis dapat membuat beberapa ide yang bisa menjadi alternatif usaha di masa Pandemi Covid 19 ini. penjualaan online menjadi solusi bagi mahasiswa untuk melakukan usaha untuk bertahan di tengah pandemi Covid-19. Masyarakat banyak berbelanja secara daring karena penerapan Pembatasan Sosial Berskala Besar (PSBB).

\section{Pembahasan}

\section{A. Kajian Literasi}

1. Technology Based Firm

TE secara langsung terkait dengan perusahaan yang berbasis teknologi baru. Menurut, Hamilton dan Kern (2001), untuk menjalankan bisnis ICT, mereka menyarankan beberapa dimensi berikut untuk pengusaha untuk struktur organisasi mereka:

a. Orang setiap individu dalam organisasi memili ki kemampuan tertentu, dan keterampilan ini b iasanya diukur terhadap matrik kinerjaformal maupun informal yang mengarah ke imbalan (kompensasi) sebagai insentif untuk kinerja $m$ asa depan;

b. Proses-proses dan metodologi yang digunakan oleh orang-orang dalam organisasi dan

c. Teknologi - keterampilan khusus dan alat yang digunakan orang dalam organisasi untuk melaksanakan fungsi-fungsi bisnis organisasi.

Hamilton dan Kern juga menambahkan bahwa konsep-konsep ini berlaku bagi setiap organisasi TE, dan secara khusus berlaku bagi organisasi pengembangan perangkat lunak, terlepas dari ukuran.

\section{Model Bisnis}

Model bisnis adalah alat yang dipakai untuk mengubah ide bisnis menjadi bisnis. Dengan model bisnis ini, realitas bisnis yang kompleks disederhanakan menjadi elemen- elemen pokok yang mudah dipahami. Istilah model bisnis pertama kali diperkenalkan dalam literatur jurnal sejak tahun 1957, namun mulai populer didiskusikan sejak tahun 1990 ke atas. Beberapa penelitian telah mengembangkan definisi dari model bisnis (Afuah dan Tucci, 2000; Afuah, 2003; Zott dan Amit, 2003; Osterwalder, 2004 dalam Hermawan, 2017). Definisi ini mengacu pada bagaimana sebuah bisnis merancang dan menjalankan usaha pembuatan nilai dan penciptaan pendapatannya (Timmers, 1998; Hamel, 2000; Afuah, 2004; Teece, 2010; dan Casadesus Masanell dan Ricart, 2010; dalam Gabriel, 2016).

Pengertian model bisnis dapat dibagi menjadi 3 unsur, yaitu:

a. Model bisnis sebagai metode atau cara

b. Model bisnis dilihat dari komponen- komponen (elemen). 
c. Model bisnis sebagai strategi bisnis.

Pengertian model bisnis sebagai metode adalah bagaimana model bisnis dapat membantu pelaku bisnis untuk menciptakan nilai dari bisnisnya yang menghasilkan keuntungan dalam sebuah rantai nilai. Model bisnis dilihat dari komponennya adalah model bisnis terdiri dari komponen produk, manfaat, pendapatan, aset, pelanggan, pengetahuan, dan lain sebagainya. Sedangkan pengertian model bisnis sebagai strategi adalah model bisnis digunakan sebagai alat untuk mengetahui kelebihan dan kelemahan usaha, sehingga bisa memanfaatkan peluang untuk menutupi resiko yang ada.(PPM Manajemen, 2012).

\section{Business Model Canvas}

Business Model Canvas (BMC) disebut-sebut sebagai alat pembuat model bisnis yang kini sangat popular dalam dunia kewirausahaan karena kemampuannya dalam menggambarkan elemen inti dalam sebuah bisnis yang dituangkan dalam satu lembar kanvas. Selain itu keunggulan BMC adalah kemudahannya untuk diubah-ubah model bisnis dengan cepat dan melihat implikasi perubahan suatu elemen pada elemen bisnis yang lain. BMC juga menyajikan model bisnis yang mengakomodasi ide-ide kreatif dan inovatif yang berasal dari banyak individu (bekerja sama) dan kemudahan untuk memadupadankannya.

Prof. Hong Y Ching, Fauvel (2013), menyoroti pentingnya penggunaan BMC dan merekomendasikannya untuk pengusaha dan dunia akademis. BMC membantu mengembangkan rencana bisnis pada pengusaha pemula dan memiliki pemahaman yang lebih holistik pada bisnis mereka. Osterwarlder, Pigneur dan Clark (2010), memperkenalkan konsep model bisnis yang bisa dimengerti semua orang, dimulai dari titik yang sama dan berbicara hal yang sama, dengan konsep yang sederhana, relevan, dan intuitif dimengerti, sementara tidak terlalu menyederhanakan kompleksitas bagaimana perusahaan berfungsi.

\section{Gambar 1. Bisnis Model Canvas Osterwalder}

BMC merupakan sebuah bentuk penyederhanaan

\begin{tabular}{|c|c|c|c|c|}
\hline \multicolumn{5}{|c|}{ OSTERWALDER'S BUSINESS MODEL CANVAS } \\
\hline \multirow{2}{*}{$\begin{array}{l}\text { Key } \\
\text { Partners }\end{array}$} & $\begin{array}{c}\text { Key } \\
\text { Activities }\end{array}$ & \multirow{2}{*}{$\begin{array}{l}\text { Value } \\
\text { Proposition }\end{array}$} & $\begin{array}{c}\text { Customer } \\
\text { Relationships }\end{array}$ & \\
\hline & $\begin{array}{l}\text { Key } \\
\text { Resources }\end{array}$ & & $\begin{array}{l}\text { Channels } \\
\text { of Distribution, } \\
\text { Sales and } \\
\text { Communication }\end{array}$ & $\begin{array}{l}\text { (niche/ } \\
\text { target) }\end{array}$ \\
\hline \multicolumn{3}{|c|}{ Costs } & \multicolumn{2}{|c|}{$\begin{array}{l}\text { Sources and amounts of } \\
\text { Revenue }\end{array}$} \\
\hline
\end{tabular}

proposal bisnis yang ditujukan untuk enterpreneur pemula dan mahasiswa yang baru memulai usaha. Untuk memudahkan membuat perencanaan bisnis dengan tujuan dari pembuatan BMC sendiri :

a. Memudahkan mahasiswa yang baru memulai usaha untuk menentukan alur bisnis yang ditekuni mulai dari segmen paling dasar.

b. Meringkas perencanaan bisnis dalam bentuk yang lebih padat. c. Sebuah proposal model baru untuk mendapatkan investasi bisnis.

d. Sebagai media justifikasi atas potensi bisnis yang hendak ditekuni.

\section{B. Metodologi}

Menurut Yin (1994) strategi penelitian harus dipilih sebagai fungsi dari melihat kondisi penelitian. Yin menunjukkan bahwa setiap strategi memiliki pendekatan sendiri yang spesifik untuk mengumpulkan dan menganalisis data empiris. Oleh karena itu strategi masing-masing memiliki kelebihan dan kelemahan.Untuk penelitian ini, studi ini digunakan pendekatan kualitatif metode penelitian.

\section{Di masa pandemi COVID-19, e-commerce diproyeksikan terus berkembang.}
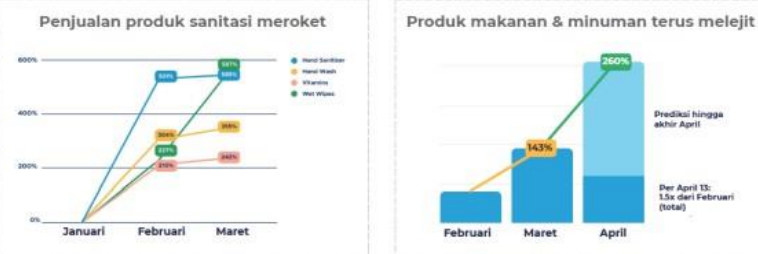

Gambar 2. Proyeksi E-commerce di masa Pandemi Covid 19

Berdasarkan data di atas menunjukan bahwa peluang usaha di bidang IT sangat menjanjikan tetapi perlu kreativitas dan ide serta di dukung dengan kemampuan melakukan pembuatan aplikasi serta di dukung metode yang tepat dalam menjalankan usaha di bidang online.

\section{Usulan BMC}

Elemen-Elemen Business Model Canvas Terdapat sembilan pilar utama dalam business model canvas di mana merangkum secara lengkap tentang bidang bisnis terkait:

a. Costumer Segment / Segmentasi Konsumen

Di pilar pertama dari BMC, hal yang dibahas adalah tentang segmentasi konsumen atau pasar yang dituju. Dalam elemen ini, perlu dijelaskan secara mendetail siapa saja yang potensial untuk menjadi konsumen dari bisnis tersebut. Dapat pula disertakan alasan mengapa target merupakan konsumen potensial.

b. Value Propositions / Proposisi Nilai Pilar kedua berisi tentang nilai atau tepatnya keunggulan dari bisnis terkait. Apa yangmembuatnya berbeda dan lebih menarik dibandingkan bidang bisnis lain. Dalam penyusulan value propositions, penting untuk mengutamakan pembahasan inovasi yang ditawarkan dalam bisnis tersebut.

c. Channel / Jalur

Jalur dalam pilar ketiga lebih mengacu pada media promosi yang hendak digunakan untuk memasarkan bisnis itu. Tentu saja, taktik promosi menjadi faktor penting dalam kesuksesan usaha. Jadi, dalam elemen bisnis model canvas kali ini akan dijelaskan rinci metode pemasaran yang efektif. 
d. Costumer Relationships / Hubungan dengan Pelanggan bagaimana cara menjaga hubungan baik sekaligus mempertahankan loyalitas konsumen merupakan elemen selanjutnya dalam business model canvas. Di pilar ini, perlu diuraikan secara terperinci perihal strategi jitu agar konsumen tidak berpindah kepada kompetitor.

e. Revenue Stream / Aliran Pendapatan Elemen kelima berkaitan dengan pendapatan bisnis. Revenue stream terbagi menjadi cost atau pendanaan dan revenue atau pendapatan. Dengan kata lain, di sini dijelaskan mengenai sumber asal modal dan objek yang berpotensi menghasilkan keuntungan.

f. Key Activities / Kegiatan Kunci

Pilar ini berhubungan dengan pilar kedua, yakni value propositions. Aktivitas apa yang dapat menciptakan nilai unggul terhadap perusahaan? Dalam pilar key activities, perlu dijabarkan perihal kegiatan yang efektif dalam meningkatkan nilai bisnis.

g. Key Resources / Sumber Daya Utama Catatan aset perusahaan secara lengkap perlu dijelaskan dalam elemen ini.

h. Key Partnership / Mitra Kunci

Salah satu kunci kesuksesan bisnis adalah menjalin kemitraan atau kerja sama. Pada elemen bisnis model canvas key partnership, dijabarkan tentang siapa saja yang potensial untuk menjalin kemitraan atau telah sukses mencapai kesepakatan kerja sama.

i. Cost Structure / Struktur Pembiayaan Pilar terakhir cukup menjebak di mana berisi tentang keterangan detail kebutuhan pendanaan untuk seluruh aktivitas bisnis.

Sembilan pilar utama $\mathrm{MBC}$ ini membantu mahasiswa dalam memulai usaha, tahapan- tahapan yang di buat sangat sederhana dalam memuala usaha. Hasil dari pembelajaran dengan mahasiswa dan sumber dari usahawan pemerintah maupun industri maka ada beberapa usaha yang bias di kembangkan selama masa SFH dan perkuliahan secara daring, Project usaha IT ini bisa menjadi salah satu acuan untuk menciptakan kreativitas, selain kemampuan dalam bidang IT dalam membuat aplikasi Web penjualan yang menarik dan bisa di informasikan kepada user dari web maupun media sosial yang untuk pemasaran produk.

Model Techopreneur IT BMC bertujuan untuk : meningkatkan kemampuana mahasiswa dalam berkreativitas, motivasi dan di dukung oleh kemampuan coding, promosi, dan keuangan sedangkan kampus menyiapkan semua sarana yang mendukung untuk kegiatan mahasiswa dan kerjasama antara lembaga dan pihak terkait menciptakan peluang usaha dan dimana para mahasiswa yang didalam perkuliahahan ini mereka di ajarkan bagaimana langsung aktif dalam usaha yang mereka tawarkan dari awal perkuliahan bersama kelompok akan menciptakan usaha online yang akan di linkkan dengan media sosial sebagai ujung tombak marketing baru. Dan munculah mahasiswa muda yang berwirausaha dan menguasai teknologi dan Aplikasi web dalam menjalankan usaha baru.menurut,Scherer,
R.F.,J.D. Brodzinsky, F.A. Wiebe, 1991;

a. Entrepreneurs / People / Student / peserta program seperti yang digambarkan dalam Sahadah, 2010; Timmons dan Spinelli, 2007; Wickham, 2004, Hisrich, Peters, dan Gembala, 2005; Bhide, 2000; Baum dan Locke, 2004, Samuelsson, 2001 dan Robert, 1991;

b. Development proses seperti yang dibahas oleh Sahadah, 2010; Bruyat dan Julien, 2001; Timmons dan Spinelli, 2007; Gartner, 1985;

c. Elemen Internal seperti lembaga pelatihan lingkungan dan faktor-faktor lingkungan seperti yang dijelaskan oleh Sahadah, 2010; Barat dan Bamford, 2005; Cruz et al, 2002;. Antonic dan Hisrich, 2003; Hynes, 1996; dan Sulaiman, 2007;

d. Elemen eksternal yaitu lingkungan universitas dan industri terkait dan faktor-faktor dukungan dari pemerintah seperti yang dibahas oleh Sahadah, 2010; Gnyawali dan Fogel 1994; Barat dan Bamford, 2005.

Tujuan dari Penerapan Techopreneur IT di perkuliahan pada masa SFH adalah:

a. Membantu mahasiswa, untuk membangun usaha mandiri dengan start-up yang di dalamnya banyak bidang usaha.

b. Menerapkan teori dalam pembelajaran TE ke dalam penjualan online.

Model ini bertujuan untuk meningkatkan kemampuan mahasiswa dalam menguasai materi dan softskill dalam wirausaha dan mencoba menciptakan usaha secara online dan menciptkaan peluang kerja dan industi baru di kampus.

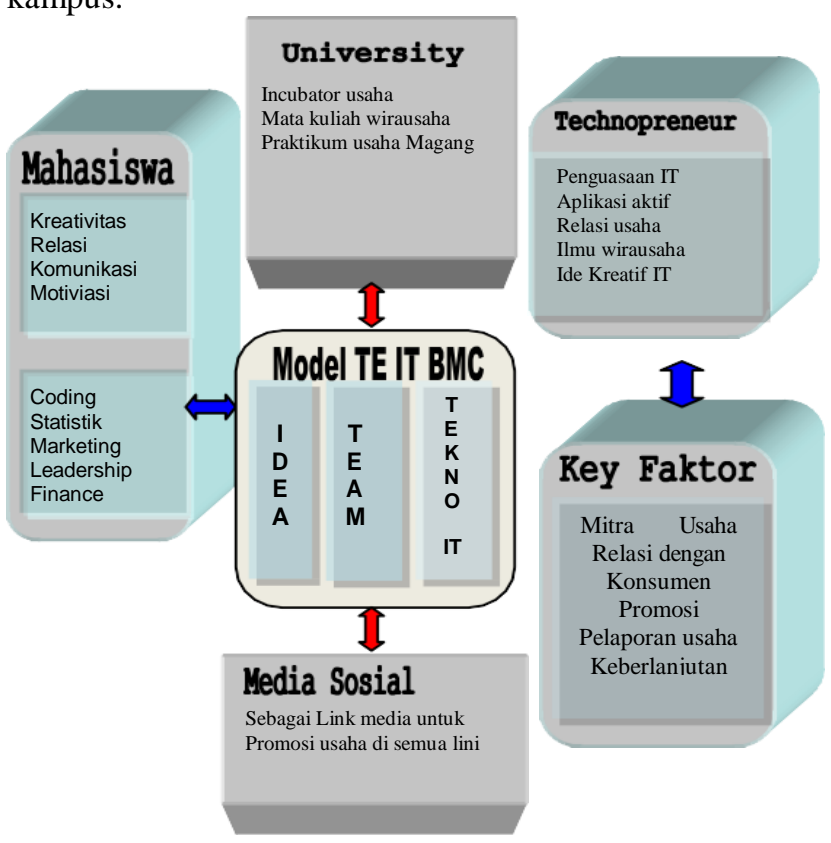

Gambar 3. Model Technopreneur IT BMC

Penerapan model di atas dengan aplikasi penjualaan Online Shop dari mahasiswa yang sedang mengambil mata kuliah Technopreneurship di Universitas IGM. Dapat di aksses di https://shopingaja.my.id/ di bawah ini format dan tampilan design yang di buat berdasarkan kebutuhan dalam penjualan. 

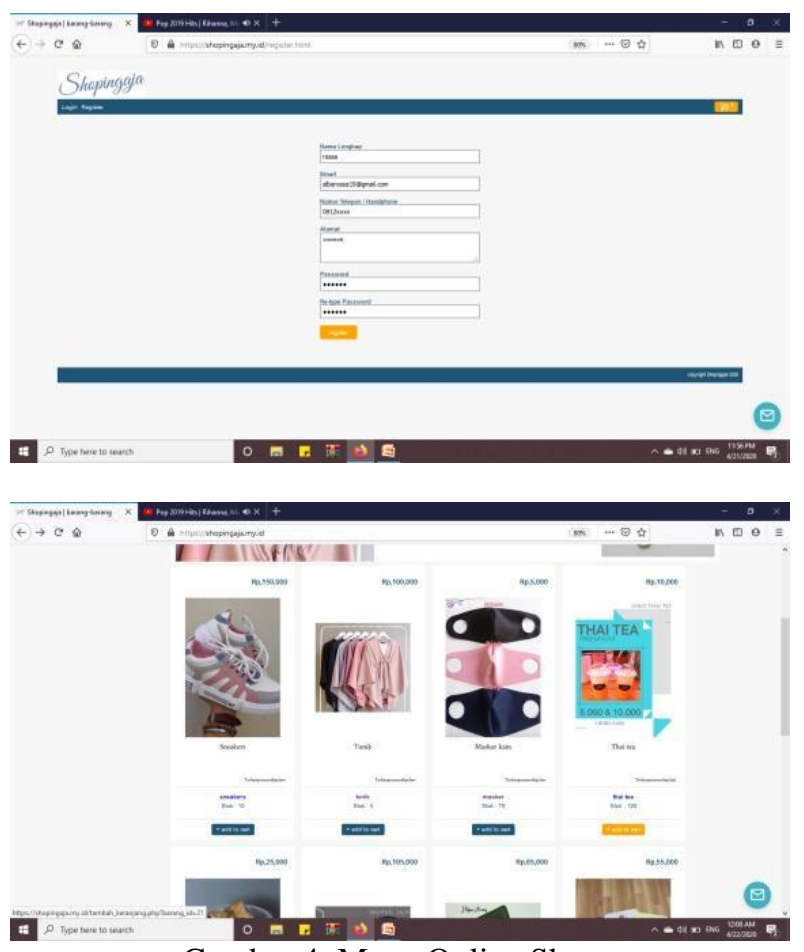

Gambar 4. Menu Online Shoop

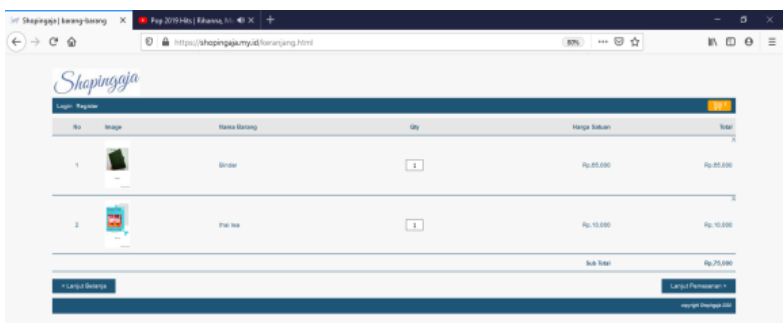

a

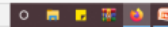

Gambar 5. Pemesanan Produk

Gambar 6. Konfirmasi Penjualaan

Semua tampilan di atas di buat seefisien mungkin dan bisa di akses oleh semua konsumen untuk melakukan transaksi secara online di mana pada masa pandemik ini semua tidak bisa melakukan secara langsung. Di harapkan semua yang di sajikan ini bisa menjadi awal mahasiswa dalam melakukan usaha secara online.

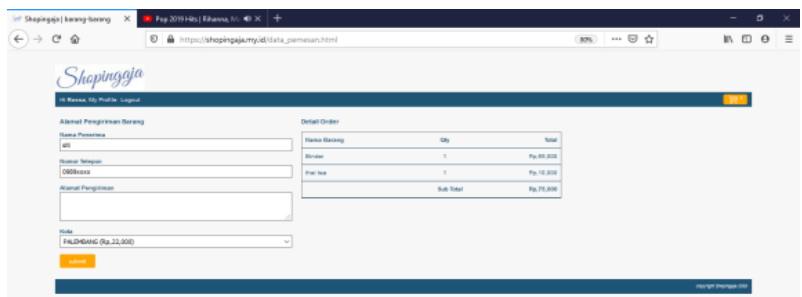

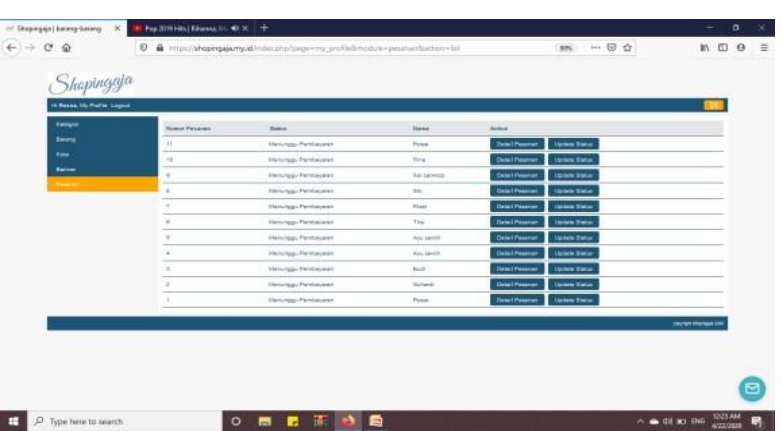

Gambar 7. Layout tampilan pesanan

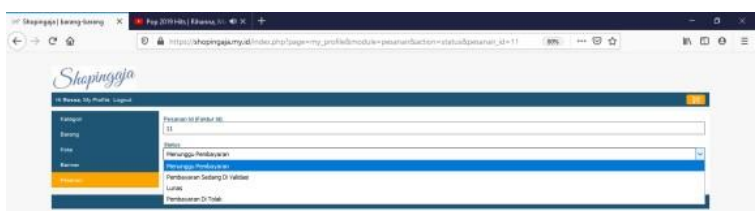

a

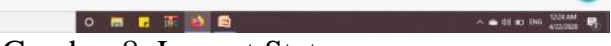

Gambar 8. Layout Status pesanan

Aplikasi penjualan online ini di bangun untuk menerapkan sistem technopreneur yabng telah di pelajari dan untuk mengimplementasikan langsung model ini dalam penerapan usaha oleh mahasiswa selama masa covid.

Di tengah pandemi ini, tentunya para pelaku brand harus bijak dalam mengalokasikan dana campaign-nya. Kreativitas saat branding itu mutlak harus dilakukan, terlebih di saat work from home seperti ini. Kegiatan branding yang dilakukan pun beragam terkait pandemik virus corona, campaign belanja dari rumah, branding melalui media online, media sosial, website official

Model Incubator ini mengusulkan kegiatan sistematis untuk mengembangkan teknologi melalui proses BMC dengan melihat situasi pasar dan usaha pada masa SFH, Kegiatan utama adalah mulai dari mencari dan memilih ide bisnis potensial dan rencana bisnis. Untuk sampai ke tingkat ini, semua Mahasiswa di dorong untuk mengajukan ide bisnis dan rencana bisnis. Dari sana di pilihalan mahasiswa dan ide bisnis yang baik akan dibuka untuk di jadikan informasi serta dukungan untuk pengembangan dan komersialisasi yaitu fasilitas usaha dan pelatihan; Jaringan bisnis, Dukungan industri dan juga dukungan finansial dari pemerintah.

\section{Kesimpulan}

Penelitian ini berfokus pada mengusulkan model technopreneur IT BMC melalui proses pembuatan usaha dari mulai mahasiswa mengikuti perkuliahan mata kuliah kewiruasahaan dan technopreneur di Universitas IGM, sehingga bisa menambah kemampuan baik secara teroritis dan praktek langsung dengan meliat peluang bersama dengan teman berkelompok bisa menciptkan ide kreatif dalam penjualaan online Studi kualitatif ini 
memberikan para peneliti dengan informasi menyeluruh yang sangat berguna dalam mengembangkan model yang di buat. Dengan lima bidang dan beberapa key faktor model ini diharapkan dapat bermanfaat bagi mahasiswa dalam mengembangkan usaha mulai dari kampus dan mengembangkan jiwa wirausaha di kalangan pemuda dan mahaasiswa untuk meningkatkan pengembangan Technopreneur di kampus dan implementasi di pasar online yang sudah menguasai trading di indonesia, dan membuka peluang-peluang bisnis online dan kreatif.

\section{Daftar Pustaka}

Aldrich, H. \& Zimmer, C. 1986. Entrepreneurship Through Social Networks, in Donald Sexton and Raymond Smilor, The Art and Science of Entrepreneurship, New York: Ballinger.

Bruyat, C. \& Julien, P.A. 2000. Defining the field of research in entrepreneurship, Journal of Business Venturing, Vol. 16 No. 2, pp.165-80.

Hynes, B. 1996. Entrepreneurship Education and Training: Introducing Entrepreneurship Into NonBusiness Disciplines. Journal of European Industrial Training, 20(8), 10-17.

Hermawan, A., Pravitasari, R.J, 2017, Business Model Canvas, Akselerasi.Id

Hong Y Ching. Prof., Clemens Fauvel, CRITICISMS, VARIATIONS AND EXPERIENCES WITH BUSINESS MODEL CANVAS, European Centre for

Research Training and Development UK (www.eajournals.org), Vol.1. No.2, pp. 26 -37, December 2013

https://aptika.kominfo.go.id/2020/05/umkm-online-jadisolusi-bertahan-saat-pandemi-covid-19/

JR.Coyanda, Sahadah A, 2010, Model Framework TechnologyEntrepreneurs Incubation Process Center In University at Indonesia. ICIEBM ,2010

R.Coyanda, 2019. Model Pembelajaran Techopreneur Meningkatkan Kemampuan Mahasiswa dalam Memulai Usaha di Universitas http://ejournal.uigm.ac.id/index.php/IG/article/view 1859

Sahadah Hj. Abdullah1,Mohd Syahrir Rahim2, John Rony Coyanda3 and Asif Zamri Zainol4, 2017, Riding the Practice of technopreneur Development: Key Motivating Factors to Participate and Graduate in Technopreneur's Masters Programs, IJER Volume $14 \cdot$ Number $22 \cdot 2017$

Schaper M. \& Volery T. 2004. Entrepreneurship And Small Business. A Pacific Rim Perspective. John Wiley. Australia.

Shaw E., O'Loughlin A. \& McFadzean E. 2005. Corporate entrepreneurship and innovation part 2: a role and process-based approach, European Journal of Innovation Management, Vol.8, No. 4. pp 393408.

Liles, P.R., 1974. New Business Ventures and the Entrepreneur, Homewood, Irwin.

cherer, R.F., J.D. Brodzinsky, F.A. Wiebe, 1991.
Intention-Based Models of Entrepreneurship Education, Napoly: 14th Annual IntEnt Conference.

Schaper M. \& Volery T. 2004. Entrepreneurship And Small Business. A Pacific Rim Perspective. John Wiley. Australia.

Sexton, D.L., N.B. Bowman, 1984. "Entrepreneurship education: Suggestions for increasing effectiveness", Journal of Small Business Managemen, vol 22(2), pp. 18-25.

Shapero, A., L. Sokol, 1982. SocialDimention of Entrepreneurship, Sexton, Kent, C.A.

Tim PPM Manajemen. 2012, Business Model Canvas Penerapan di Indonesia 